\title{
Direct ROS Scavenging Activity of CueP from Salmonella enterica serovar Typhimurium
}

\author{
Bo-Young Yoon ${ }^{1}$, Ji-Hyun Yeom², Jin-Sik Kim¹, Si-Hyeon Um¹, Inseong Jo', Kangseok Lee ${ }^{2}$, \\ Yong-Hak Kim ${ }^{3,4, *}$, and Nam-Chul $\mathrm{Ha}^{1,4, *}$
}

\begin{abstract}
Salmonella enterica serovar Typhimurium (S. Typhimurium) is an intracellular pathogen that has evolved to survive in the phagosome of macrophages. The periplasmic copper-binding protein CueP was initially known to confer copper resistance to $S$. Typhimurium. Crystal structure and biochemical studies on CueP revealed a putative copper binding site surrounded by the conserved cysteine and histidine residues. A recent study reported that CueP supplies copper ions to periplasmic $\mathrm{Cu}, \mathrm{Zn}$-superoxide dismutase (SodCII) at a low copper concentration and thus enables the sustained SodCIl activity in the periplasm. In this study, we investigated the role of CueP in copper resistance at a high copper concentration. We observed that the survival of a cueP-deleted strain of Salmonella in macrophage phagosome was significantly reduced. Subsequent biochemical experiments revealed that CueP specifically mediates the reduction of copper ion using electrons released during the formation of the disulfide bond. We observed that the copper ion-mediated Fenton reaction in the presence of hydrogen peroxide was blocked by CueP. This study provides insight into how CueP confers copper resistance to $S$. Typhimurium in copper-rich environments such as the phagosome of macrophages.
\end{abstract}

\section{INTRODUCTION}

Copper is ubiquitous in nature and is required for all living organisms (Crichton and Pierre, 2001). Copper ions are involved in catalyzing many biochemical reactions due to easy conversion between the cuprous $\left(\mathrm{Cu}^{+}\right)$and cupric $\left(\mathrm{Cu}^{2+}\right)$ forms (Leary and Winge, 2007). However, they are also involved in generating free radicals in the presence of oxygen or hydrogen perox-

\footnotetext{
${ }^{1}$ College of Pharmacy and Research Institute for Drug Development, Pusan National University, Busan 609-735, Korea, ${ }^{2}$ Department of Life Science, Chung-Ang University, Seoul 156-756, Korea, ${ }^{3}$ Department of Microbiology, Catholic University of Daegu, School of Medicine, Daegu 705-718, Korea, ${ }^{4}$ These authors contributed equally to this work.

*Correspondence: hnc@pusan.ac.kr (NCH); ykim@cu.ac.kr (YHK)
}

Received 27 August, 2013; revised 5 December, 2013; accepted 18 December, 2013; published online 19 February, 2014

Keywords: copper resistance, CueP, Fenton reaction, Salmonella ide and excess copper ions (Halliwell and Gutteridge, 1984). To cope with the dual nature of copper ions, all living organisms tightly control cellular copper pools with elaborate copper homeostatic mechanisms (O'Halloran and Culotta, 2000), including copper-responsive transcriptional regulators, membrane transporters and copper chaperones (Franke et al., 2003; Osman and Cavet, 2008; Pontel and Soncini, 2009; Rensing et al., 2000).

Salmonella enterica serovar Typhimurium ( $S$. Typhimurium) is an important human pathogen that causes worldwide foodassociated Salmonella gastrointestinal disease (Coburn et al., 2007). The ability of the bacteria to survive in macrophage phagosomes is associated with its virulence (Fields et al., 1986). Since copper ions participate in killing the invading pathogens in the phagosomes of the activated macrophages and neutrophils in the Fenton reaction (Dupont et al., 2011; Hodgkinson and Petris, 2012), copper resistance of the bacteria has been implicated in the ability of the bacteria to survive in the phagosomes of macrophages (Achard et al., 2012; White et al., 2009b). Thus copper resistance of some intracellular pathogens is now considered an important virulence factor (Prohaska and Lukasewycz, 1981; White et al., 2009a; Wolschendorf et al., 2011).

In $S$. Typhimurium, elevated copper ions are exported via either one of two related P1B-type ATPases, CopA and GolT, which are essential in the survival of the bacteria in excessive copper environments (Osman et al., 2010). The expression of CopA and GolT in $S$. Typhimurium is triggered by the coppersensing transcriptional regulator CueR leading to copperresponsive expression of the proteins (Espariz et al., 2007). CueR also mediated the expression of the multi-copper oxidase CueO (Rensing et al., 2000) and the periplasmic copperbinding protein CueP (Espariz et al., 2007; Osman et al., 2010; Pontel and Soncini, 2009).

CueP was initially known to confer copper resistance to $S$. Typhimurium as a functional replacement of the $\mathrm{Cu}^{+}$-specific exporter CusAFBC found in most Gram-negative bacteria (Pontel and Soncini, 2009). The CueP-deleted strain of S. Typhimurium was highly susceptible to copper, particularly in anaerobiosis (Pontel and Soncini, 2009). Crystal structure and biochemical studies of CueP revealed a putative copper binding site surrounded by the conserved cysteine and histidine residues (Yoon et al., 2013). A recent study reported that the CueP protein in complex with copper ion supplies copper ion to periplasmic $\mathrm{Cu}, \mathrm{Zn}$-superoxide dismutase (SodCII) at a low 
concentration of copper, and thus sustains the SodCII activity that is implicated in the bacterial virulence (Osman et al., 2013). However, the biochemical role of CueP remains to be elucidated in excessive copper environments. In this study, we investigate the role of CueP in scavenging formation of the hydroxyl radical from $\mathrm{H}_{2} \mathrm{O}_{2}$ in the presence of high concentrations of copper ion.

\section{MATERIALS AND METHODS}

\section{Bacterial strains and plasmids}

The DNA construction, protein expression, and protein purification of $S$. Typhimurium CueP (residues 22-179 in the numbering of the precursor CueP) has been previously described (Yun et al., 2011). Salmonella Typhimurium SL1344 deleted for cueP was obtained by the $\lambda$ Red method (Datsenko and Wanner, 2000) using primers that have been previously used by Osman et al. (2010): 5'- GGAACCCCTATAGTAGGCAGGGAGATTGT TCACAAGGAATTGAAGTTATGGTGTAGGCTGGAGCTGCT T-3' and 5'-GATAACCCATTATGTTATCGGGCATTTTITTAA CGTAATGGTAATTCCGTCATATGAATATCCTCCTTA-3'. To construct plasmids for expression of $c u e P$ and its variants in $E$. coli, full-length $S$. Typhimurium CueP, including the promoter region, was amplified using PCR primers $5^{\prime}$-GCATGAATTCAC TITACCCTGCGTCCCT-3', and 5'-GCATCCATGGTAACCCA TTATGTTATCG-3', digested with EcoRI and Ncol, and ligated into pACYC184 vector. The mutations H94A, C96S, H99A, C104S and C172S were introduced into the cloned wild-type cueP gene by two subsequent PCR reactions (Landt et al., 1990). To construct a plasmid for expression of cueP in S. Typhimurium, plasmid pACYC177-CueP was constructed by ligating PCR DNA digested with BamHI and Hindlll into the same site of PACYC177. PCR DNA containing the coding region of CueP was synthesized using two primers, 177cuePF (5'-GATCAAGCTTACTTTACCCTGCGTCCCT-3') and 177cue PR (5'-GATCGGATCCTAACCCATTATGTTATCG-3').

\section{Size exclusion chromatography}

To determine the molecular size of CueP or to confirm its dimeric form in solution, size-exclusion chromatography was performed at a flow rate of $0.5 \mathrm{ml} / \mathrm{min}$ on Superdex S-200 HR 10/30 (GE Healthcare) equilibrated with $20 \mathrm{mM}$ Tris buffer $(\mathrm{pH}$ 8.0) containing $150 \mathrm{mM} \mathrm{NaCl}$ and $2 \mathrm{mM}$ 2-mercaptoethanol.

\section{Preparation of the CueP protein sample}

Since the wild-type and mutant CueP proteins contain $2 \mathrm{mM} 2$ mercaptoethanol to prevent oxidation, 2-mercaptoethanol was removed from the sample buffer by extensive dialysis against highly-degassed $20 \mathrm{mM}$ Tris buffer ( $\mathrm{pH}$ 8.0) containing $150 \mathrm{mM}$ $\mathrm{NaCl}$. After dialysis, the protein samples were concentrated and stored at $-80^{\circ} \mathrm{C}$ until use.

Measurement of free sulfhydryl contents by using DTNB Free cysteine residues of wild-type and mutant CueP proteins were determined by using the 5,5'-dithiobis(2-nitrobenzoic acid) (DTNB) assay (Ellman, 1959) with modification. The purified protein samples $(0.2 \mathrm{mM})$ were incubated with $0.5 \mathrm{mM} \mathrm{CuCl}_{2}$ at room temperature for $1 \mathrm{~min}$. Then, $10 \mu \mathrm{l}$ of the incubated sample were taken in $75 \mu \mathrm{l}$ of $30 \mathrm{mM}$ Tris buffer ( $\mathrm{pH}$ 8.2) containing $3 \mathrm{mM}$ EDTA solution. Subsequently, $5 \mathrm{mM}$ DTNB and $99 \%$ methanol (vol) were added and incubated for $15 \mathrm{~min}$ at room temperature. After centrifugation at $13,000 \mathrm{rpm}$ for $5 \mathrm{~min}$, 2nitro-5-thiobenzoate produced from the disulfide bond cleavage of DTNB by thiol group of cysteine was quantified by mea- surement of the absorption at $412 \mathrm{~nm}[\varepsilon=14,150 / \mathrm{M} \mathrm{cm}$ : (Ellman, 1959)].

Electron paramagnetic resonance spectroscopy

Copper sulfate standard solution $(0.2 \mathrm{mM})$ in $20 \mathrm{mM}$ Tris buffer (pH 8.0) containing $150 \mathrm{mM} \mathrm{NaCl}$ was prepared and the EPR spectra were recorded at $-196^{\circ} \mathrm{C}$ with $0.01 \mathrm{~mW}$ microwave power on a Beckman X-band CW-EPR (Beckman Coulter). Upon performing baseline correction, the spectra were doubleintegrated from 2500 to $3500 \mathrm{G}$. The copper peak at $3250 \mathrm{G}$ was clearly identified. The protein sample $(70 \mu \mathrm{M})$ was added to the $\mathrm{CuCl}_{2}$-containing buffer and incubated for $5 \mathrm{~min}$ at room temperature, and then the EPR spectra were collected. The concentration of $\mathrm{Cu}^{2+}$ was calculated by integrating the peak around $3250 \mathrm{G}$ corresponding to $\mathrm{Cu}^{2+}$.

\section{Hydroxyl radical scavenging assay}

To prepare the CueP protein in the reduced or oxidized state, the purified protein was treated with $2 \mathrm{mM} 2$-mercatoethanol or $0.5 \mathrm{mM} \mathrm{CuCl}_{2}$, respectively, and then dialyzed against highly degassed $20 \mathrm{mM}$ Tris buffer containing $150 \mathrm{mM} \mathrm{NaCl}$ at $4^{\circ} \mathrm{C}$. The protein was used for this study within $1 \mathrm{~h}$ after dialysis. One $\mu \mathrm{l}$ of $\mathrm{CuCl}_{2}(5 \mu \mathrm{M}$ as a final concentration) was added into $10 \mu$ l of each protein sample $(5 \mu \mathrm{M})$ in $20 \mathrm{mM}$ Hepes buffer $(\mathrm{pH}$ 7.0) and incubated for $10 \mathrm{~min}$ at room temperature. Then, $10 \mu \mathrm{l}$ of supercoiled plasmid ( $1 \mu \mathrm{g}$; pPROEX-HTA, Invitrogen) containing $2 \mathrm{mM} \mathrm{H}_{2} \mathrm{O}_{2}$ was added and incubated for $5 \mathrm{~min}$ at $22^{\circ} \mathrm{C}$ and applied to $0.8 \%$ agarose gel electrophoresis to examine the levels of intact (supercoiled) and open circle plasmid bands.

\section{Sample preparation for mass spectrometry}

The mature form of CueP (residues 22-179) was incubated at a concentration of $1 \mathrm{mg} / \mathrm{mL}(56.7 \mu \mathrm{M}$ monomer) in $1 \times \mathrm{PBS}$ buffer $\left(8.5 \mathrm{~g} \mathrm{NaCl}, 0.2 \mathrm{~g} \mathrm{KCl}, 1.78 \mathrm{Na}_{2} \mathrm{HPO}_{4}, 0.27 \mathrm{~g} \mathrm{KH}_{2} \mathrm{PO}_{4}\right.$ in $1 \mathrm{~L}$ $\mathrm{H}_{2} \mathrm{O}, \mathrm{pH}$ 7.4) with or without addition of $0.1 \mathrm{mM} \mathrm{CuCl}_{2}$ for 15 min at room temperature. Each sample was treated with $6 \mathrm{M}$ urea and $100 \mathrm{mM} \mathrm{N}$-ethylmaleimide (NEM) for $1 \mathrm{~h}$ in the dark to derivatize free thiol groups of cysteine residues and then treated with $2 \mathrm{M}$ trichloroacetic acid (TCA) to stop the NEM reaction and induce the acidolytic cleavage of the Cu-thiolate bond in CueP, which was then allowed to precipitate for $15 \mathrm{~min}$ on ice. After centrifugation for $10 \mathrm{~min}$, the supernatant was removed and the pellet was washed twice with pre-chilled $80 \%$ acetone. The air-dried protein was dissolved in $50 \mathrm{mM}$ Tris/ $\mathrm{HCl}$ (pH 8.0) containing $6 \mathrm{M}$ urea and $100 \mathrm{mM}$ iodoacetamide (IAA) to derivatize the $\mathrm{Cu}$-free thiol groups for $1 \mathrm{~h}$ in the dark. Then, the protein was precipitated with 2 M TCA and $80 \%$ acetone. For the analysis of disulfide bond in the CueP monomer excised from a non-denaturing SDS-PAGE gel, in-gel protein digestion was performed with trypsin and chemotrypsin, as described previously (Yoon et al., 2013), and peptides were cleaned up using ZipTip ${ }^{\circledR}$ C18 for mass spectrometry.

\section{Mass spectrometry}

Peptide samples were dissolved in $0.4 \%$ acetic acid and analyzed as previously described with an LTQ-Velos mass instrument (Thermo Fisher Scientific Inc.) equipped with EASY-nLC 1000 Liquid Chromatograph (Yoon et al., 2013). The acquired mass spectral data were analyzed by SEQUEST search algorithm (Eng et al., 1995) with the options of average mass $(\mathrm{m} / \mathrm{z})$; precursor mass tolerance, $0.8 \mathrm{Da}$; fragment mass tolerance, $0.8 \mathrm{Da}$; variable modifications for cysteine, including NEM $(\mathrm{m} / \mathrm{z}$ difference, 125.125), carbamidomethylation with IAA (57.021), oxidation (15.995) and dioxidation (31.999), and histidine pro- 
tonation (1.008). Disulfide-bonded peptides were analyzed by in-house Excel program with the option of $2 \mathrm{H}$ loss (-2.016) from all combinations of 2 peptides, each containing cysteine. The extracted ion chromatograms (XIC) were generated by Thermo Xcalibur Qual Browser 2.1 with the precursor ion mass $(\mathrm{m} / \mathrm{z})$ and mass tolerance of 0.2 Da.

\section{Sensitivity of E. coli harboring S. Typhimurium CueP to the} Fenton reaction

To see the effect of $S$. Typhimurium CueP in $E$. coli strain BW25113 under cusB-deleted background, the $E$. coli strain BW25113 $\triangle$ cusB was obtained from KEIO collection (Yamamoto et al., 2009). Wild-type or mutant $S$. Typhimurium cueP gene was inserted into a pACYC184 vector, as described above. The vector was transformed into the $E$. coli strain, and the $E$. coli was grown in $\mathrm{LB}$ at $37^{\circ} \mathrm{C}$ until $\mathrm{OD}_{600}$ range of $0.7-0.9$. The cells were immediately washed with pre-warmed $20 \mathrm{mM}$ Hepes buffer ( $\mathrm{pH} 7.5)$ two times and then incubated with 0.1 $\mathrm{mM} \mathrm{CuCl}_{2}$ in $20 \mathrm{mM}$ Hepes buffer for $15 \mathrm{~min}$ at room temperature. After washing the cells two times with $20 \mathrm{mM}$ Hepes buffer (pH 7.5), $30 \mathrm{mM} \mathrm{H}_{2} \mathrm{O}_{2}$ was added to the cells for $5 \mathrm{~min}$. To measure the survival of the bacteria, the cells were spread on LB agar plates.

\section{Cell culture and macrophage infections}

Macrophages were infected with S. Typhimurium strain SL1344 and its isogenic strain deleted for the cueP gene $(\triangle c u e P)$ by the method described by Osman et al. (2010). To restore the cueP gene, pACYC177-CueP was transformed to $\triangle$ cueP or wild-type strain of $S$. Typhimurim. For infection, RAW264.7 macrophage cells obtained from the Korean Cell Line Bank (Korea) were cultivated under $5 \% \mathrm{CO}_{2}$ at $37^{\circ} \mathrm{C}$ in RPMl 1640 (Welgene) supplemented with $10 \%(\mathrm{v} / \mathrm{v})$ fetal bovine serum (Welgene). Wild-type and $\triangle c u e P S$. Typhimurium strains were grown overnight in LB media at $37^{\circ} \mathrm{C}$ and $200 \mathrm{rpm}$. The bacteria were washed and resuspended in sterile D-PBS $(8.5 \mathrm{mM}$ sodium phosphate, $1.5 \mathrm{mM}$ potassium phosphate, $137 \mathrm{mM}$ $\mathrm{NaCl}, \mathrm{pH} 7.4$ ) to mix into the RAW264.7 cell cultures at a multiplicity of infection (MOI) of 10:1 (bacteria:macrophage). At 2-h post-infection, the cell culture media were replaced with serumfree media supplemented with $200 \mu \mathrm{g} / \mathrm{ml}$ gentamicin to kill extracellular bacteria for $2 \mathrm{~h}$. The infected RAW264.7 cells were then washed with D-PBS and intracellular bacteria were released with $0.1 \%$ Triton $X-100$, followed by incubation at $37^{\circ} \mathrm{C}$ for $5 \mathrm{~min}$. The number of intracellular bacteria was assessed by viable counts on non-selective and selective LB agar plates.

\section{Western blot analysis}

Protein concentrations of CueP and ribosomal protein $\mathrm{S} 1$ in whole-cell extracts were determined using a rabbit polyclonal anti-CueP and aniti-S1 antibody. Standard ECL reagents and films (GE Healthcare Life Sciences, USA) were used for Western blot detection with horseradish peroxidase (HRP)-conjugated anti-rabbit IgG antibody (Santa Cruz Biotechnology, Inc., USA). Specific proteins were imaged by using a VersaDoc 100 instrument (Bio-Rad, USA) and quantified by using Quantity One (Bio-Rad). The polyclonal anti-CueP antibody was raised in rabbits, which were immunized with the purified recombinant CueP protein (Ab Frontier, Korea). Polyclonal antibodies to S1 were obtained from Dr. Stanley N. Cohen (Stanford University).

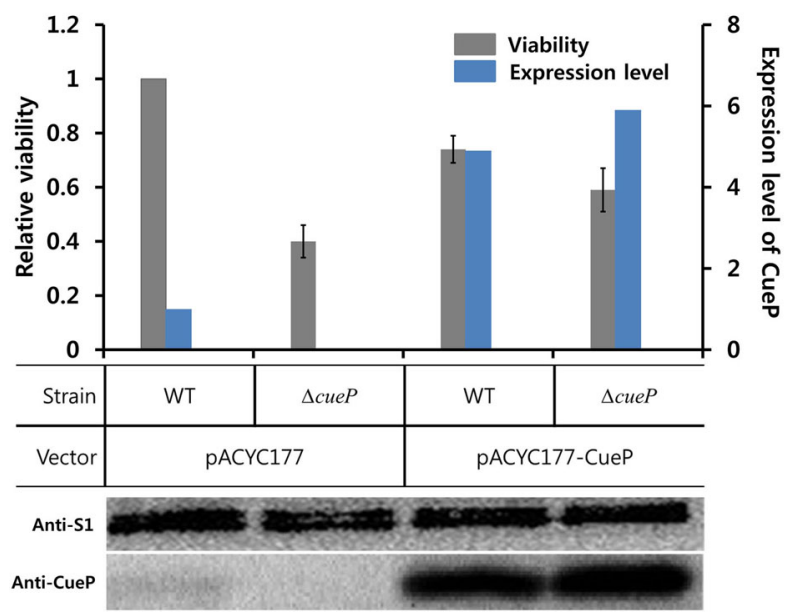

Fig. 1. The role of CueP in the survival of Salmonella in macrophage phagosomes. Relative viability of Salmonella strains was measured in murine macrophage RAW264.7 cells. Infection assays were performed with wild-type S. Typhimurium (WT) and cuePdeleted $(\triangle c u e P)$ strains, transformed with pACYC177 vector or pAcyC177-CueP that harbors the wild cueP gene. Relative viability index was defined as the colony-forming unit ratio of mutant and wild-type strains. In each case, bacterial strains were used at a final MOI of 10:1. Data points represent the mean $( \pm$ S.E) for at least three independent experiments. Total proteins of wild-type and cueP-deleted $(\triangle \mathrm{cueP})$ strains of $S$. Typhimurium were separated by SDS-PAGE and analyzed in Western blot using anti-CueP and antiS1 antibodies. The expression level of CueP, assessed by the Western blot analysis, is displayed in the right y axis.

\section{RESULTS}

The survival of cueP-deleted strain of $S$. Typhimurium in macrophage is significantly decreased

Salmonella can survive within macrophage phagosomes, and this survival is critical for bacterial virulence during systemic disease (Fields et al., 1986). To examine the role of CueP in the survival of the bacteria in the macrophage phagosomes, we deleted the cueP gene in virulent $S$. Typhimurium (strain SL1344) to compare its survivals with that of the wild-type strain when infecting the murine macrophage cell line RAW264.7. As shown in Fig. 1, the survival of the $\triangle c u e P$ strain was markedly decreased in the mouse macrophage cell line (by about $60 \%$ ). However, the survivals of the bacteria were lower than those of the wild-type strain when the cueP gene was overexpressed in the wild-type or cueP-deleted strain of $S$. Typhimurium. This observation suggests that the cueP gene is constitutively expressed in Salmonella, which has evolved to survive in the macrophage phagosome.

\section{A disulfide bond between Cys96 and Cys104 is formed by $\mathrm{Cu}^{2+}$}

To examine how CueP biochemically contributes to the pathogenesis of $S$. Typhimurium, we investigated the involvement of the CueP protein with copper ion. $\mathrm{CuCl}_{2}$ specifically induces a disulfide bond of the protein according to SDS-PAGE under non-reducing conditions (Pontel and Soncini, 2009). In this study, mass spectrometric analysis was employed to determine which cysteine residues were engaged in the disulfide bond 

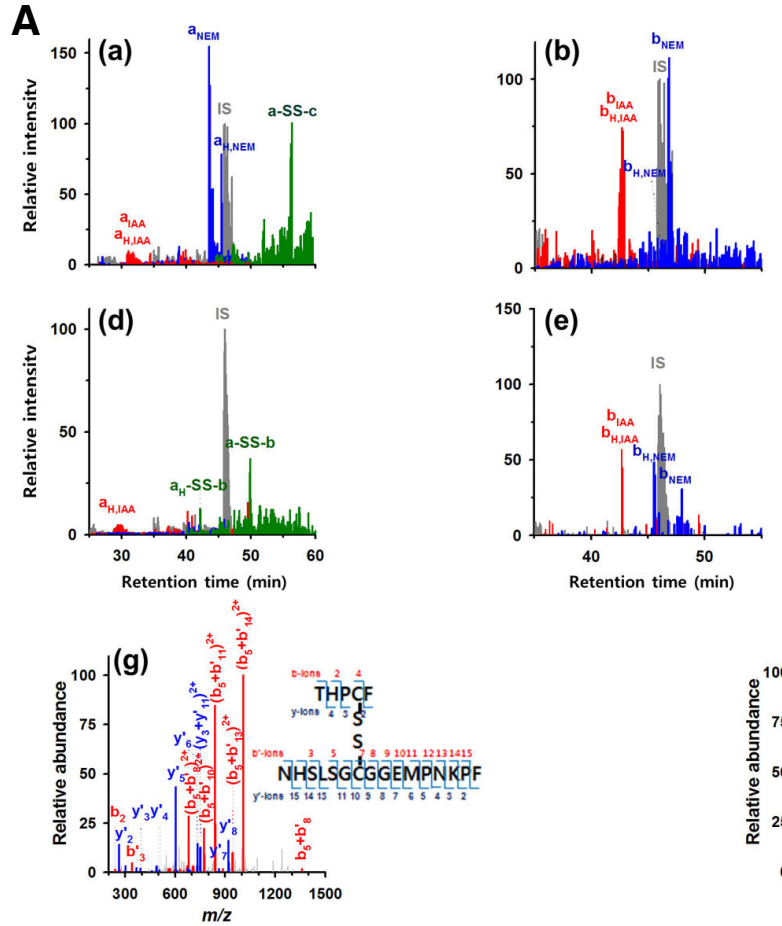

B

\section{MSKSSWLLLL GLCASGSALA ASSESAFLAQ HGLAGKTVEQ IVDTIDQTPQ SRPLPYSASI 60}

61 TSTELKLSDG EQIYTLPLGD KFYLSFAPYE WRTḦPČFNH้ LSG 121 KGAVIVQKEM QSYRNGFIGV WLPRNMEGTL EVSYNGKTAS HAIATSDDSQ TČLTELPLR 179

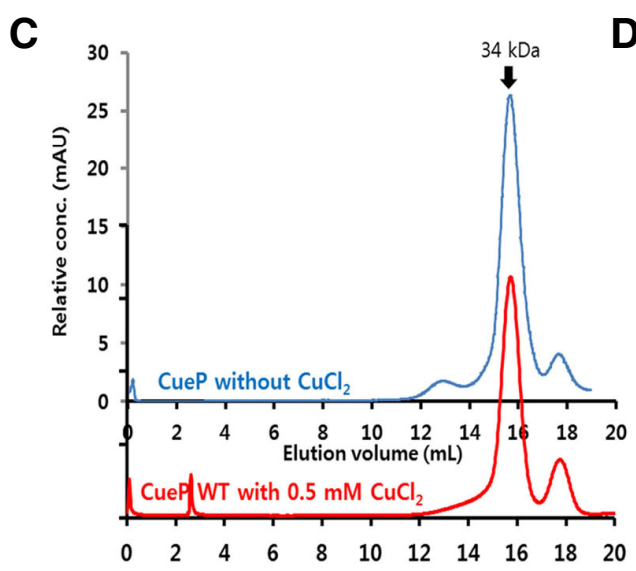

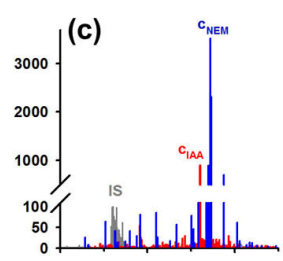
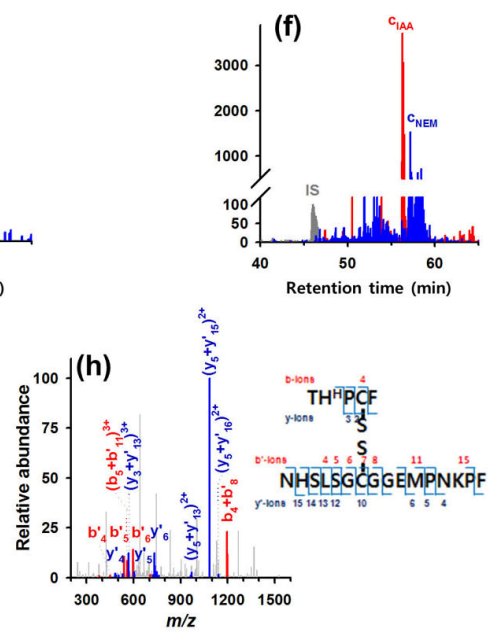

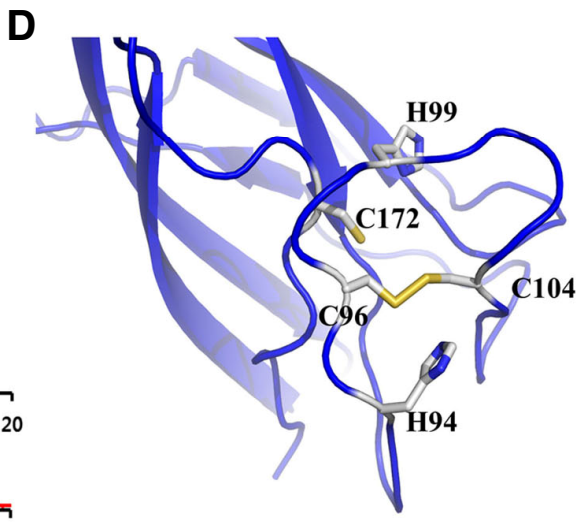
size exclusion chromatography. The reduced form of wild-type CueP protein $\left(\mathrm{CueP}\right.$ without $\left.\mathrm{CuCl}_{2}\right)$ and the oxidized protein by addition
of $0.5 \mathrm{mM} \mathrm{CuCl}_{2}\left(\mathrm{CueP}\right.$ with $\left.\mathrm{CuCl}_{2}\right)$ are subject to size exclusion chromatography (Superdex 200 10/30) in a highly-degassed buffer containing $20 \mathrm{mM}$ Tris- $\mathrm{HCl}$ and $150 \mathrm{mM} \mathrm{NaCl}$ at a flow rate of $0.5 \mathrm{ml} / \mathrm{min}$. To oxidize the protein with CuCl $\mathrm{C}_{2}$, the wild-type $\mathrm{CueP}$ protein $\left(1 \mathrm{mg} / \mathrm{ml}\right.$ ) was incubated with $0.5 \mathrm{mM} \mathrm{CuCl}_{2}$ for $30 \mathrm{~min}$ at room temperature $\left(\mathrm{CueP}\right.$ with $\left.\mathrm{CuCl}_{2}\right)$. The elution profile of $\mathrm{CueP}_{\text {with }} \mathrm{CuCl}_{2}$ was offset for clarity. (D) A molecular model for the Cys-rich region of CueP in the oxidized state, induced by $\mathrm{CuCl}_{2}$. The side chains of His94, Cys96, His99, Cys104, and Cys172 are shown.

bridge induced by $\mathrm{Cu}^{2+}$. When exposed to $\mathrm{CuCl}_{2}$, the $\mathrm{CueP}$ protein formed the disulfide bond between Cys96 and Cys104 in the monomer subunits separated by non-reducing SDSPAGE (Fig. 2A). In comparison with the untreated sample, the $\mathrm{CuCl}_{2}$-treated CueP protein had marked decreases in the free

Fig. 2. Disulfide bond between Cys96 and Cys104, induced by $\mathrm{CuCl}_{2}$. (A) Merged graphs of extracted ion chromatograms (XICs) of cysteine-containing peptides in the CueP monomers excised from a non-denaturing SDS PAGE gel. Prior to gel separation, the CueP proteins were incubated for $15 \mathrm{~min}$ in the absence $(\mathrm{a}-\mathrm{c})$ or presence (d-f) of $0.1 \mathrm{mM} \mathrm{CuCl}_{2}$ at room temperature. The peaks of precursor ions of ${ }^{93} \mathrm{THPCF}^{97},{ }^{98} \mathrm{NHSLSG}$ CQGEMPNKPF ${ }^{113}$ and ${ }^{162}$ TASHA IATSDDSQTCLTELPLR ${ }^{183}$ are shown with the respective letters, $a, b$ and $c$, followed by the subscripts: $\mathrm{H}$, histidine protonation at His94 $\left(\mathrm{a}_{\mathrm{H}}\right)$ or His99 $\left(\mathrm{b}_{\mathrm{H}}\right)$; NEM or IAA, alkylation of cysteine with $\mathrm{N}$ ethylmaleimide or iodoacetamide; and -SS-, disulfide bond between two peptides. The relative intensity of a unique peptide, LSDGEQIY $(\mathrm{m} / \mathrm{z}=462.99, z=+2$ at RT 46.0 min), used as internal standard (IS), is expressed as 100 for each chromatogram. Disulfide-bonded peptides, a-SS-b and $a_{\mathrm{H}}-\mathrm{SS}-\mathrm{b}$, derived from the $\mathrm{CuCl}_{2}$-treated CueP protein, are identified by tandem mass spectra assigned to the $b$ - and $y$ ions generated from collisioninduced fragmentation of the precursor ions at $\mathrm{m} / \mathrm{z}=759.85$ and 760.19 in the charge states of +3 , and tandem mass spectral data for the other peptide peaks are shown in Supplementary Fig. S1. (B) Amino acid sequence of $S$. Typhimurium CueP. The key conserved residues are in red, of which the strictly conserved Cys and His residues are indicated by *. The disulfide bond bridge is shown in a red line with 'S-S', which is induced by $\mathrm{CuCl}_{2}$. The signal sequence is shown in gray. (C) The molecular size of the CueP protein when oxidized by $\mathrm{Cu}^{2+}$, measured by 

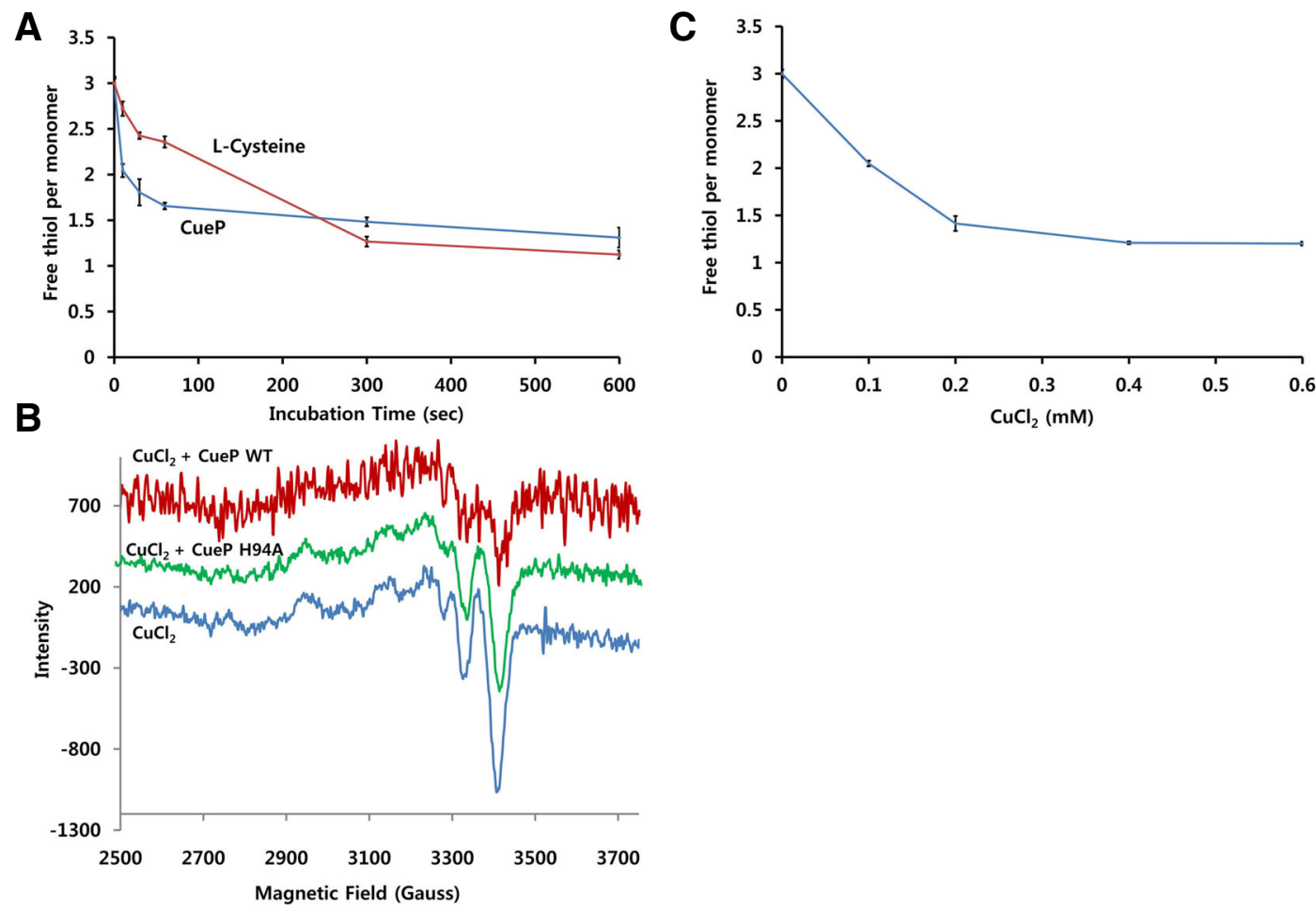

Fig. 3. The rapid reaction of CueP with $\mathrm{Cu}^{2+}$. (A) Comparison of the reactivity of CueP to $\mathrm{Cu}^{2+}$ with L-cysteine. Prior to the experiment, wildtype CueP protein was dialyzed against $20 \mathrm{mM}$ Tris buffer $(\mathrm{pH} 8.0)$ containing $150 \mathrm{mM} \mathrm{NaCl}$. The protein concentration of CueP was measured based on the molar extinction coefficient. The CueP protein $(0.2 \mathrm{mM})$ or L-cysteine $(0.6 \mathrm{mM})$, dissolved in Tris buffer, was incubated with $0.5 \mathrm{mM} \mathrm{CuCl}_{2}$ for a given time. The error bars indicate the standard deviation from three independent experiments. The free thiol group was quantified using the agent DTNB by measuring absorbance at $412 \mathrm{~nm}$. (B) Representative EPR spectra of $\mathrm{Cu}^{2+}$ around $3400 \mathrm{G}$ in the presence/absence of wild-type or variant CueP. The sample containing $0.5 \mathrm{mM} \mathrm{CuCl}_{2}$ and wild-type or $\mathrm{H} 94 \mathrm{~A}$ CueP protein $(0.4 \mathrm{mM})$ was incubated for $5 \mathrm{~min}$ at room temperature and then applied to EPR at $-197^{\circ} \mathrm{C}$. More than three independent experiments were performed and produced similar results. Each spectrum was offset for clarity. (C) Titration with $\mathrm{CuCl}_{2}$ to the oxidation of CueP. Each amount of $\mathrm{CuCl}_{2}$ was incubated with $0.2 \mathrm{mM}$ CueP protein for $15 \mathrm{~min}$, and then the free thiol content was measured using the agent DTNB. The error bars indicate the standard deviation from three independent experiments.

while decreasing the free thiol level ( $\mathrm{C}_{\text {NEM }}$ ), as shown in Fig. $2 A(f)$. Otherwise, a certain amount of Cys172 formed the disulfide bond with Cys96 in the absence of $\mathrm{CuCl}_{2}$ [Fig. $\left.2 \mathrm{~A}(\mathrm{a})\right]$. The mass spectral data showed that the disulfide bond between the conserved residues Cys96 and Cys 104 was newly made by addition of $\mathrm{Cu}^{2+}$ (Fig. 2B) and differed from the disulfide bond (Cys96 and Cys172) induced by molecular oxygen (Yoon et al., 2013). This implies that copper ion induces a conformational change of the CueP protein to generate the disulfide bond between Cys96 and Cys104 instead of Cys172, which participated in metal binding or spontaneous oxidation of the CueP protein. The cysteine oxidation by $\mathrm{CuCl}_{2}$ did not change the oligomeric state of the CueP protein, as assessed by size exclusion chromatography (Fig. $2 \mathrm{C}$ ), indicating that the disulfide bond is formed in an intramolecular manner.

The crystal structure of CueP showed a putative copper binding site, consisting of the conserved residues Cys96, Cys104, Cys172, His94, and His99 (Yoon et al., 2013). Based on the crystal structure (Yoon et al., 2013), we modeled the putative copper binding site (referred to as cysteine-rich region in this study) in the oxidized state, which is induced by $\mathrm{CuCl}_{2}$ (Fig. 2D). The model seems reasonable because the crystal structure revealed that the distance between the thiol groups of Cys96 and Cys104 is relatively short, and the loop containing Cys104 is intrinsically flexible (Yoon et al., 2013).

\section{CueP is rapidly oxidized by $\mathrm{Cu}^{2+}$ with a stoichiometry of $1: 1$}

We next examined how fast the disulfide bond of CueP is formed in response to $\mathrm{Cu}^{2+}$, using the agent DTNB to selectively react with the free thiol groups with a short reaction time (Ellman, 1959). To compare the reactivity of the cysteine residues in CueP with the authentic cysteine in solution, threetimes higher concentration of L-cysteine was used since one molecule of CueP has three cysteine residues. As shown in Fig. $3 \mathrm{~A}$, all the cysteine residues of the purified CueP protein are in the reduced state since the free thiol contents of CueP and Lcysteine were the same at the initial stage. When $\mathrm{CuCl}_{2}$ was added to the CueP protein in a reducing-agent-free buffer, twothirds of the free thiol was rapidly consumed, which is consistent with the mass spectrometry result revealing the disulfide bond between Cys96 and Cys104 of CueP. In contrast, $\mathrm{Cu}^{2+}$ slowly decreased the free thiol content of L-cysteine (Fig. 3A).

Since $\mathrm{Cu}^{2+}$ brings about the oxidation of $\mathrm{CueP}$, we undertook an electron paramagnetic resonance spectroscopy (EPR) investigation to verify the reduction of $\mathrm{Cu}^{2+}$ by $\mathrm{CueP}$. The wild- 

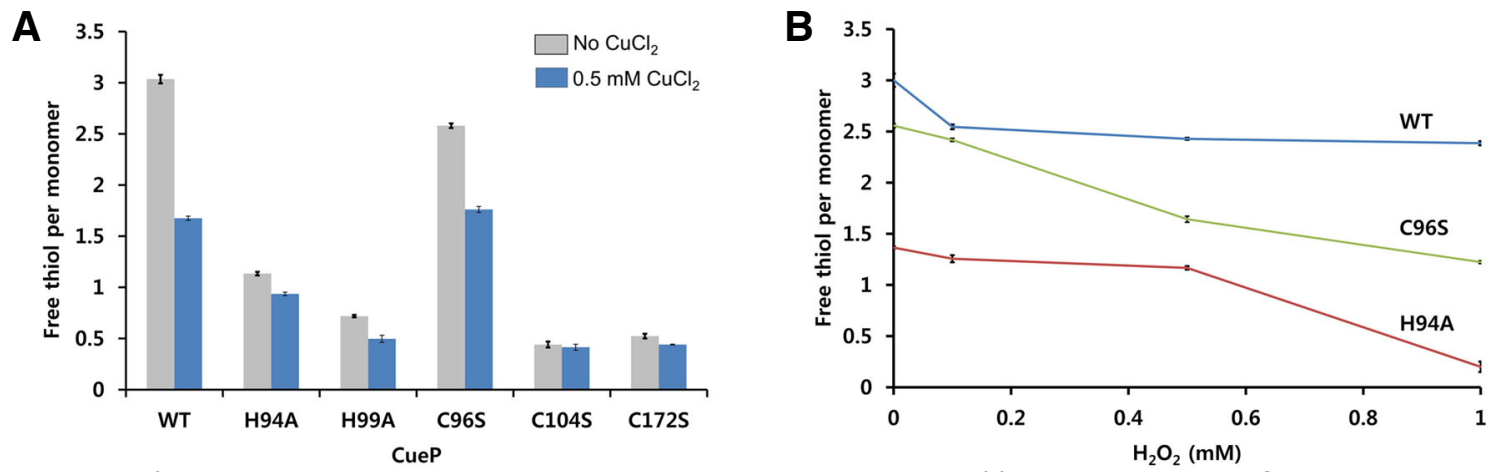

Fig. 4. The role of the conserved residues in the cysteine-rich region. (A) The amount of free thiol group in the CueP proteins (wild-type and mutants), measured using the agent DTNB. Freshly prepared protein sample $(0.2 \mathrm{mM})$ was incubated with 0 or $0.5 \mathrm{mM} \mathrm{CuCl} \mathrm{m}_{2}$ for $1 \mathrm{~min}$ in 20 $\mathrm{mM}$ Tris buffer $\left(\mathrm{pH} 8.0\right.$ ) containing $150 \mathrm{mM} \mathrm{NaCl}$, and then subjected to the assays. (B) Reactivity of CueP to $\mathrm{H}_{2} \mathrm{O}_{2}$. Each CueP protein (0.2 $\mathrm{mM}$ ) was incubated with the indicated concentration of $\mathrm{H}_{2} \mathrm{O}_{2}$ for $15 \mathrm{~min}$, and then the free thiol contents were measured using the agent DTNB. Only wild-type (WT), H94A and C96S mutants are displayed. The mutant proteins H99A, C104S, and C172S are displayed in Supplementary Fig. S3.

type CueP protein decreased the concentration of $\mathrm{Cu}^{2+}$ by converting it to a more reduced form of $\mathrm{Cu}\left(\mathrm{Cu}^{+}\right.$or $\left.\mathrm{Cu}^{0}\right)$ (Fig. 3B). However, a non-functional mutant (H94A; see below) CueP did not result in this reaction and was used as a control. Unfortunately, we were not able to distinguish whether the product of this reaction is $\mathrm{Cu}^{+}$or $\mathrm{Cu}^{0}$ because both $\mathrm{Cu}^{+}$and $\mathrm{Cu}^{0}$ are undetectable in EPR.

To further analyze the reaction product, we titrated the oxidation of CueP $(200 \mu \mathrm{M})$ with $\mathrm{CuCl}_{2}$. When the molar ratio of CueP to $\mathrm{Cu}^{2+}$ was about 1 , the oxidation of CueP was saturated (Fig. $3 \mathrm{C}$ ). This result suggests that the stoichiometry of CueP to $\mathrm{Cu}^{2+}$ is $\sim 1$, and one $\mathrm{Cu}^{2+}$ is required to form one disulfide bond in CueP. However, an NMR-based experiment indicated that one electron was transferred from L-cysteine to $\mathrm{Cu}^{2+}$, resulting in $1 / 2$ cystine and $\mathrm{Cu}^{+}$(Rigo et al., 2004). Therefore, our result suggests that the disulfide bond formation of CueP, which provides two electrons, is coupled to the transition of $\mathrm{Cu}^{2+}$ to $\mathrm{Cu}^{0}$.

His94, His99 and Cys104 play an important role in maintaining the reduced state of CueP in the absence of $\mathrm{Cu}^{2+}$

To investigate the role of the conserved cysteine and histidine residues at the cysteine-rich region, we mutated Cys96, Cys104, Cys172, His94, and His99 into serine or alanine and measured the free thiol concentrations of the proteins in reducing agent-free buffer. To see the changes in the oxidation states of the proteins, we also compared the free thiol concentrations of the proteins before and after exposure to $0.5 \mathrm{mM}$ $\mathrm{CuCl}_{2}$ (Fig. 4A). Among the five mutants, H99A, C104S, and C172S exhibited significantly decreased free thiol concentrations, even prior to exposure to $\mathrm{CuCl}_{2}$, (Fig. 4A). H94A also displayed a decreased free thio concentration in the absence of $\mathrm{CuCl}_{2}$, albeit the decreasing amount was smaller than H994, C104S, and C172S variant protein. However, the C96S had significant fractions of free thiol before addition of $\mathrm{CuCl}_{2}$ and were partly oxidized by the addition of $\mathrm{CuCl}_{2}$ although the oxidation rates were less than those of the wild-type protein. The most protein of C172S mutant existed as a tetramer on a size exclusion chromatography, indicating that the intermolecular disulfide bonds were easily formed in this mutant protein (Supplementary Fig. S2).
We next measured the sensitivity of CueP to oxidative stress produced by $\mathrm{H}_{2} \mathrm{O}_{2} . \mathrm{H}_{2} \mathrm{O}_{2}$ did not efficiently decrease the amount of free thiol in wild-type CueP within 15 min (Fig. 4B). In this experiment, C96S and H94A made the mutant protein more sensitive to oxidation by $\mathrm{H}_{2} \mathrm{O}_{2}$ than wild-type $\mathrm{CueP}$, although the mutant protein conferred some resistance to oxidation by molecular oxygen in reducing agent-free buffer. By contrast, the other mutant proteins (H99A, C104S, and C172S) had been already oxidized by oxygen during the dialysis against the reducing agent-free buffer, so the proteins were not further oxidized by $\mathrm{H}_{2} \mathrm{O}_{2}$ (Supplementary Fig. S3).

CueP efficiently scavenges $\mathrm{Cu}^{2+}$-mediated Fenton reaction The $\mathrm{Cu}^{2+}$ titration indicated that CueP catalyzes the conversion of $\mathrm{Cu}^{2+}$ to $\mathrm{Cu}^{0}$. Since elemental copper $\mathrm{Cu}^{0}$ cannot catalyze the Fenton reactions, we expected that the CueP protein would inhibit the Fenton reactions by depleting copper ions. Thus we tested whether CueP can prevent the $\mathrm{Cu}^{2+} / \mathrm{Cu}^{+}$-mediated Fenton reaction in vitro. The CueP protein was incubated in a reaction mixture containing supercoiled plasmids and $\mathrm{CuCl}_{2}$, to which $\mathrm{H}_{2} \mathrm{O}_{2}$ was added in order to trigger the Fenton reaction. Supercoiled plasmids were used to probe the generation of hydroxyl radicals in this experiment, because hydroxyl radicals, but not $\mathrm{H}_{2} \mathrm{O}_{2}$, can make a single strand breakage in the plasmid, leading to the generation of an open-circle plasmid (Netto et al., 1996). As shown in Fig. 5A, the CueP protein in the reduced state protected more than $50 \%$ of the DNA from hydroxyl radicals, whereas the protein in the oxidized state resulted in the complete DNA cleavage. We next performed the same assay to observe the dose-dependent effect of the reduced CueP protein. Interestingly, CueP showed maximum hydroxyl radical scavenging activity at the molar ratio of 1:1 (CueP: $\left.\mathrm{Cu}^{2+}\right)$, and the activity disappeared when more CueP protein was added. At the molar ratio of $4: 1$, the scavenging activity was decreased by about $50 \%$, compared to the maximum scavenging activity at the molar ratio of $1: 1$. These results indicate that the ratio of the protein to $\mathrm{Cu}^{2+}$ might affect the chemical reaction (Fig. 5B). These results show that the CueP protein could diminish the Fenton reaction by reducing the copper ion to elemental copper at the expense of a disulfide bond in a certain range of the protein concentration.

To examine the importance of the conserved cysteine and 
A
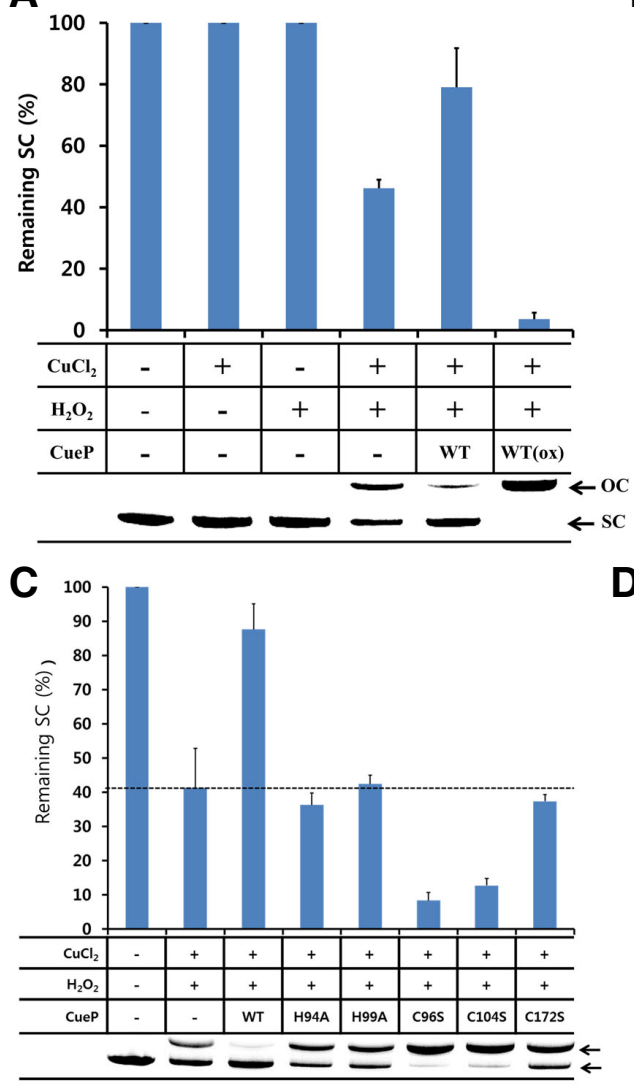

B
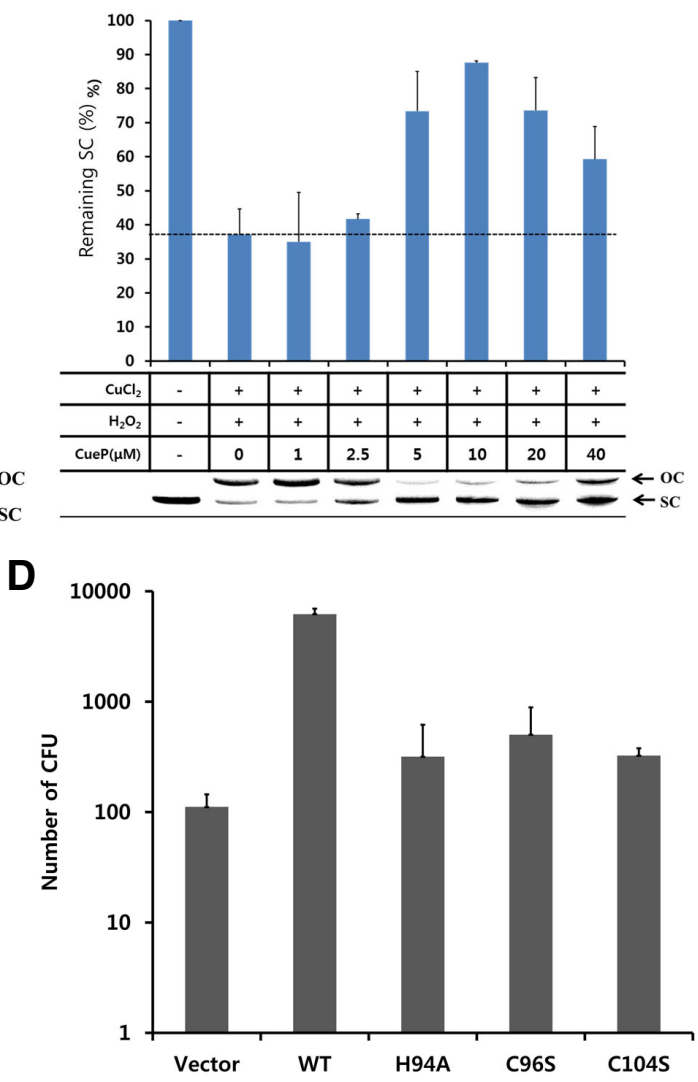

Fig. 5. CueP prevents the copper ion-mediated Fenton reaction. (A) An assay for hydroxyl radicals generated from $\mathrm{H}_{2} \mathrm{O}_{2}$ in the presence of the copper ion using supercoiled plasmid. The hydroxyl radicals cleave the supercoiled plasmid (SC) into the open circle form (OC). After reaction of the reduced (CueP ${ }^{\text {red }}$ ) or oxidized $\left(\mathrm{CueP}^{\mathrm{Ox}}\right)$ form of CueP protein with $10 \mu \mathrm{M}$ $\mathrm{CuCl}_{2}$, the plasmid and 2 $\mathrm{mM} \mathrm{H}_{2} \mathrm{O}_{2}$ was added and incubated for $5 \mathrm{~min}$ at room temperature and then immediately subjected to agarose gel electrophoresis ( $0.8 \%$ ). The DNA was visualized by $\mathrm{EtBr}$ staining. Data points represent the mean for two independent experiments. A representative gel figure is shown in the bottom. (B) The hydroxyl radical formation assay in a dose-dependent manner of the CueP protein. The reduced form of CueP was added to the reaction mixture as indicated. The reaction conditions are the same as in Fig. 5A. Data points represent the mean $( \pm$ S.E) for at least three independent experiments. The dashed-line indicates the level of the remaining supercoiled plasmid in the absence of CueP in our experimental condition for the Fenton reaction. A representative gel figure is shown in the bottom. (C) The role of the conserved cysteine or histidine residues in preventing the formation of hydroxyl radicals in the presence of $\mathrm{Cu}^{2+}$ and $\mathrm{H}_{2} \mathrm{O}_{2}$. The same amount of wild-type or mutant CueP proteins was added to the reaction mixture. The reaction conditions are the same as in Fig. 5A. Data points represent the mean ( \pm S.E) for at least three independent experiments. The dashed-line indicates the level of the remaining supercoiled plasmid in the absence of CueP in our experimental condition for the Fenton reaction. A representative gel figure is shown in the bottom. (D) The effect of $S$. Typhimurium CueP in E. coli under cusB-deleted background. Wild-type or mutant $S$. Typhimurium cueP was inserted into pACYC177 vector, and the vector was transformed into the $E$. coli strain. Exponentially grown E. coli in LB was immediately washed with $20 \mathrm{mM}$ Hepes buffer $(\mathrm{pH} 7.5)$ at room temperature. The cells were incubated with $0.1 \mathrm{mM} \mathrm{CuCl} 2$ in $20 \mathrm{mM}$ Hepes buffer to allow the copper ions to diffuse into the bacterial cell and then washed with copper-free buffer. $\mathrm{H}_{2} \mathrm{O}_{2}(30 \mathrm{mM})$ was incubated with the cell for $5 \mathrm{~min}$ to induce the Fenton reaction within the cell, and then the cells were plated to measure the survival of the bacteria. Data points represent the mean $( \pm$ S.E) for at least three independent experiments.

histidine residues, the hydroxyl radical scavenging assays were performed with mutant proteins. As shown in Fig. 5C, any single mutation at the conserved residues completely abolished the DNA protection activity of CueP. Some of the mutants (C96S and C104S) rather accelerated the reaction. Thus, these cysteine and histidine residues together play an important role in the inhibition of the Fenton reactions by the CueP action on the copper ion in the presence of $\mathrm{H}_{2} \mathrm{O}_{2}$.

\section{CueP increases the survival of $E$. coli in Fenton reaction} Iron ions are sequestered to limit the growth of bacteria in macrophage phagosome, although iron ions mediate the Fenton reaction in the presence of $\mathrm{H}_{2} \mathrm{O}_{2}$ (Schaible and Kaufmann, 2004). Instead, copper ions are transported to the phagosome to enhance the toxicity of ROS or RNS (Leary and Winge, 2007; White et al., 2009b). To examine whether the purified
CueP protein can protect the live bacteria from the Fenton reaction mediated by copper ions, we introduced the cueP gene, including its copper-responsive promoter region, into the cusB-deleted strain of $E$. coli. As experimental controls, the empty vector or the non-functional mutants (H94A, C96S and C104S) were also transformed to evaluate the role of wild-type CueP. Exponentially grown cells were washed with $20 \mathrm{mM}$ Hepes buffer and incubated with $0.1 \mathrm{mM} \mathrm{CuCl}_{2}$ for diffusion into the bacterial cell. After washing the cells with copper-free buffer, the cells were treated with $30 \mathrm{mM} \mathrm{H}_{2} \mathrm{O}_{2}$ for 5 min to induce the Fenton reaction and then cultivated on LB agar plate to measure the survival of the bacteria.

Neither $\mathrm{CuCl}_{2}$ nor $\mathrm{H}_{2} \mathrm{O}_{2}$ treatment alone significantly killed the bacteria (Fig. 5D). In contrast, when treated with $\mathrm{CuCl}_{2}$ and $\mathrm{H}_{2} \mathrm{O}_{2}$ together, $E$. coli cells expressing wild-type CueP showed higher survivals by about 100 times than those harboring an 
empty vector or a mutant gene. This result indicated that wildtype CueP was able to protect $E$. coli cells against copper ionmediated $\mathrm{H}_{2} \mathrm{O}_{2}$ decomposition, which generates hydroxyl radicals as the ultimate cell-killing agents. However, the mutant CueP proteins showed a marginal or similar effect to empty vector, which failed to protect against the cell-killing effects of $\mathrm{CuCl}_{2}$ and $\mathrm{H}_{2} \mathrm{O}_{2}$. Therefore, the conserved histidine and cysteine residues are crucial for CueP's role.

We found an inconsistency in the experimental results using the mutants. In the DNA protection assay using the purified proteins, some of the mutant proteins showed the decreased DNA scavenge activities compared to that in the absence of the CueP protein used as a control (Fig. $5 \mathrm{C}$ ). However, when the mutant $c u e P$ was expressed in $E$. coli, the mutant $c u e P$ partly contributed to the survival of the bacteria in the experimental condition (Fig. 5D). We speculate that this inconsistency might results from a beneficial role of the expressed CueP in E. coli. For example, the CueP mutants, expressed in the E. coli periplasm, could transfer a copper ion to the periplasmic SodCIl, as observed in S. Typhimurium (Osman et al., 2013).

\section{DISCUSSION}

Many pathogenic bacteria can evade or resist the bacterial cell killing mechanism of macrophages. In the intracellular bacteria $S$. enterica, the periplasmic protein CueP was identified as a functional substitute for the Cus $\mathrm{Cu}^{+}$efflux pump (Pontel and Soncini, 2009). Previously, CueP from $S$. Typhimurium was suggested to transfer a copper ion to SodCll in the periplasm at a low copper concentration, leading to activation of SodCII (Osman et al., 2013). In this study, we studied the biochemical role of CueP at a higher concentration of copper. Since the copper levels are elevated and accumulate in the phagosome of macrophages exposed to inflammatory cytokines via specific transporters (Achard et al., 2012; White et al., 2009a; Wolschendorf et al., 2011), our results suggest that CueP may be associated with the pathogenesis of the bacteria in the macrophage phagosomes.

Copper ions can catalyze the Fenton reaction by alternating between $\mathrm{Cu}^{+}$and $\mathrm{Cu}^{2+}$, and consequently generate highly toxic hydroxyl radicals (Czech et al., 1974). $\mathrm{Cu}^{+}$mediates the decomposition of $\mathrm{H}_{2} \mathrm{O}_{2}$ by transferring one electron, generating the hydroxyl radical, hydroxide ion, and $\mathrm{Cu}^{2+}$ (reaction 1); $\mathrm{Cu}^{2+}$ is then reduced back to $\mathrm{Cu}^{+}$by a complex series of chain reactions from $\mathrm{H}_{2} \mathrm{O}_{2}$ (reaction 2). These reactions continue generating hydroxyl radicals until all $\mathrm{H}_{2} \mathrm{O}_{2}$ is consumed (Bae et al., 2011). Since the rate of reaction 1 is significantly greater than that of reaction 2, the generation rate of hydroxyl radical in solution is limited by the regeneration of $\mathrm{Cu}^{+}$. When L-cysteine is added, the conversion of $\mathrm{Cu}^{+}$from $\mathrm{Cu}^{2+}$ is accelerated, resulting in formation of cysteine (Cys-Cys) (reaction 3).

$$
\begin{aligned}
& \mathrm{Cu}^{+}+\mathrm{H}_{2} \mathrm{O}_{2} \rightarrow \mathrm{Cu}^{2+}+{ }^{\circ} \mathrm{OH}+\mathrm{OH}^{-} \\
& \mathrm{Cu}^{2+}+\mathrm{H}_{2} \mathrm{O}_{2} \rightarrow \mathrm{Cu}^{+}+{ }^{\circ} \mathrm{OOH}+\mathrm{H}^{+} \\
& 2 \mathrm{Cu}^{2+}+2 \mathrm{Cys}^{2} \mathrm{Cu}^{+}+\mathrm{Cys}-\mathrm{Cys} \\
& \mathrm{Cu}^{2+}+\mathrm{CueP}_{2 \mathrm{Cys}} \rightarrow \mathrm{Cu}^{0}+\mathrm{CueP}_{\text {Cys-Cys }}
\end{aligned}
$$

(reaction 1) (reaction 2) (reaction 3) (reaction 4)

Our results suggest that the reduced form of $\mathrm{CueP}\left(\mathrm{CueP}_{2 \mathrm{Cys}}\right)$ catalyzes the conversion of $\mathrm{Cu}^{2+}$ to $\mathrm{Cu}^{0}$, as described in reaction 4. Since $\mathrm{Cu}^{0}$ is not able to mediate the Fenton reaction in the presence of $\mathrm{H}_{2} \mathrm{O}_{2}$, the CueP reaction with $\mathrm{Cu}^{2+}$ attenuates the formation of hydroxyl radical. In a previous report, CueP partly restored the copper resistance of the cus-deleted strain of $E$. coli, particularly under anaerobic conditions (Pontel and
Soncini, 2009). This observation is well explained by the $\mathrm{Cu}^{2+}$ reducing activity of CueP revealed in this study. Reduction of copper ions by CueP can protect the bacteria from the copper ion-mediated decomposition of $\mathrm{H}_{2} \mathrm{O}_{2}$ to hydroxyl radical, considered the ultimate cell-killing agent of the phagosome. Since the reaction of CueP with copper ion is free of an oxygen molecule and relatively insensitive to molecular oxygen and $\mathrm{H}_{2} \mathrm{O}_{2}$, it can act either under anaerobic or aerobic conditions. These properties confer CueP with a great advantage over the copper oxidase CueO (Grass and Rensing, 2001). In the presence of $\mathrm{H}_{2} \mathrm{O}_{2}$, the reaction product of $\mathrm{CueO}, \mathrm{Cu}^{2+}$, contributes to Fenton chemistry (reaction 2), although it can reduce the rate of hydroxyl radical generation by $\mathrm{Cu}^{+}$(reaction 1). However, CueP can block the total Fenton reactions by the conversion of copper ions to elemental copper atoms.

$S$. Typhimurium causes critical diseases for animals including humans, leading to substantial morbidity, mortality and a considerable disease burden globally (Coburn et al., 2007). Since the gene deletion or mutation of the highly conserved amino acids of CueP diminishes the ability of pathogens to live in the host immune cells, CueP may be a good target in the development of antibacterial agents. Furthermore, the results of this study will increase our understanding of the roles of copper tolerance at the host-pathogen interface.

Note: Supplementary information is available on the Molecules and Cells website (www.molcells.org).

\section{ACKNOWLEDGMENTS}

This research was supported by a 2-Year Research Grant of Pusan National University.

\section{REFERENCES}

Achard, M.E., Stafford, S.L., Bokil, N.J., Chartres, J., Bernhardt, P.V., Schembri, M.A., Sweet, M.J., and McEwan, A.G. (2012). Copper redistribution in murine macrophages in response to Salmonella infection. Biochem. J. 444, 51-57.

Bae, Y.S., Oh, H., Rhee, S.G., and Yoo, Y.D. (2011). Regulation of reactive oxygen species generation in cell signaling. Mol. Cells 32, 491-509.

Coburn, B., Grassl, G.A., and Finlay, B.B. (2007). Salmonella, the host and disease: a brief review. Immunol. Cell Biol. 85, 112-118.

Crichton, R.R., and Pierre, J.L. (2001). Old iron, young copper: from Mars to Venus. Biometals 14, 99-112.

Czech, M.P., Lawrence, J.C., Jr., and Lynn, W.S. (1974). Evidence for electron transfer reactions involved in the $\mathrm{Cu}^{2+}$-dependent thiol activation of fat cell glucose utilization. J. Biol. Chem. 249, 1001-1006.

Datsenko, K.A., and Wanner, B.L. (2000). One-step inactivation of chromosomal genes in Escherichia coli K-12 using PCR products. Proc. Natl. Acad. Sci. USA 97, 6640-6645.

Dupont, C.L., Grass, G., and Rensing, C. (2011). Copper toxicity and the origin of bacterial resistance--new insights and applications. Metallomics 3, 1109-1118.

Ellman, G.L. (1959). Tissue sulfhydryl groups. Arch. Biochem. Biophys. $82,70-77$.

Eng, J.K., McCormack, A.L., and Yates, J.R. (1995). An approach to correlate tandem mass spectral data of peptides with amino acid sequences in a protein database. J. Am. Soc. Mass Spectrom 5, 976-989.

Espariz, M., Checa, S.K., Audero, M.E., Pontel, L.B., and Soncini, F.C. (2007). Dissecting the Salmonella response to copper. Microbiology 153, 2989-2997.

Fields, P.I., Swanson, R.V., Haidaris, C.G., and Heffron, F. (1986). Mutants of Salmonella typhimurium that cannot survive within the macrophage are avirulent. Proc. Natl. Acad. Sci. USA 83, 5189-5193.

Franke, S., Grass, G., Rensing, C., and Nies, D.H. (2003). Molecular analysis of the copper-transporting efflux system CusCFBA 
of Escherichia coli. J. Bacteriol. 185, 3804-3812.

Grass, G., and Rensing, C. (2001). CueO is a multi-copper oxidase that confers copper tolerance in Escherichia coli. Biochem. Biophys. Res. Commun. 286, 902-908.

Halliwell, B., and Gutteridge, J.M. (1984). Oxygen toxicity, oxygen radicals, transition metals and disease. Biochem. J. 219, 1-14.

Hodgkinson, V., and Petris, M.J. (2012). Copper homeostasis at the host-pathogen interface. J. Biol. Chem. 287, 13549-13555.

Landt, O., Grunert, H.P., and Hahn, U. (1990). A general method for rapid site-directed mutagenesis using the polymerase chain reaction. Gene 96, 125-128.

Leary, S.C., and Winge, D.R. (2007). The Janus face of copper: its expanding roles in biology and the pathophysiology of disease. Meeting on Copper and Related Metals in Biology. EMBO Rep. 8, 224-227.

Netto, L.E.S., Chae, H.Z., Kang, S.W., Rhee, S.G., and Stadtman, E.R. (1996). Removal of hydrogen peroxide by thiol-specific antioxidant enzyme (TSA) is involved with its antioxidant properties. TSA possesses thiol peroxidase activity. J. Biol. Chem. $271,15315-15321$

O'Halloran, T.V., and Culotta, V.C. (2000). Metallochaperones, an intracellular shuttle service for metal ions. J. Biol. Chem. 275, 25057-25060.

Osman, D., and Cavet, J.S. (2008). Copper homeostasis in bacteria. Adv. Appl. Microbiol. 65, 217-247.

Osman, D., Waldron, K.J., Denton, H., Taylor, C.M., Grant, A.J., Mastroeni, P., Robinson, N.J., and Cavet, J.S. (2010). Copper homeostasis in Salmonella is atypical and copper-CueP is a major periplasmic metal complex. J. Biol. Chem. 285, 2525925268.

Osman, D., Patterson, C.J., Bailey, K., Fisher, K., Robinson, N.J., Rigby, S.E., and Cavet, J.S. (2013). The copper supply pathway to a Salmonella $\mathrm{Cu}, \mathrm{Zn}$-superoxide dismutase (SodCII) involves $\mathrm{P}(1 \mathrm{~B})$-type ATPase copper efflux and periplasmic CueP. Mol. Microbiol. 87, 466-477.

Pontel, L.B., and Soncini, F.C. (2009). Alternative periplasmic copper-resistance mechanisms in Gram negative bacteria. Mol. Microbiol. 73, 212-225.
Prohaska, J.R., and Lukasewycz, O.A. (1981). Copper deficiency suppresses the immune response of mice. Science 213,559 561.

Rensing, C., Fan, B., Sharma, R., Mitra, B., and Rosen, B.P. (2000) CopA: An Escherichia coli Cu(I)-translocating P-type ATPase. Proc. Natl. Acad. Sci. USA 97, 652-656.

Rigo, A., Corazza, A., di Paolo, M.L., Rossetto, M., Ugolini, R., and Scarpa, M. (2004). Interaction of copper with cysteine: stability of cuprous complexes and catalytic role of cupric ions in anaerobic thiol oxidation. J. Inorg. Biochem. 98, 1495-1501.

Schaible, U.E., and Kaufmann, S.H. (2004). Iron and microbial infection. Nat. Rev. Microbiol. 2, 946-953.

White, C., Kambe, T., Fulcher, Y.G., Sachdev, S.W., Bush, A.I. Fritsche, K., Lee, J., Quinn, T.P., and Petris, M.J. (2009a). Copper transport into the secretory pathway is regulated by oxygen in macrophages. J. Cell Sci. 122, 1315-1321.

White, C., Lee, J., Kambe, T., Fritsche, K., and Petris, M.J. (2009b). A role for the ATP7A copper-transporting ATPase in macrophage bactericidal activity. J. Biol. Chem. 284, 33949-33956.

Wolschendorf, F., Ackart, D., Shrestha, T.B., Hascall-Dove, L., Nolan, S., Lamichhane, G., Wang, Y., Bossmann, S.H., Basaraba, R.J., and Niederweis, M. (2011). Copper resistance is essential for virulence of Mycobacterium tuberculosis. Proc. Natl. Acad. Sci. USA 108, 1621-1626.

Yamamoto, N., Nakahigashi, K., Nakamichi, T., Yoshino, M., Takai, Y., Touda, Y., Furubayashi, A., Kinjyo, S., Dose, H., Hasegawa M., et al. (2009). Update on the Keio collection of Escherichia coli single-gene deletion mutants. Mol. Syst. Biol. 5, 335.

Yoon, B.Y., Kim, Y.H., Kim, N., Yun, B.Y., Kim, J.S., Lee, J.H., Cho, H.S., Lee, K., and Ha, N.C. (2013). Structure of the periplasmic copper-binding protein CueP from Salmonella enterica serovar Typhimurium. Acta Crystallogr. D Biol. Crystallogr. 69, 1867-1875.

Yun, B.Y., Piao, S., Kim, Y.G., Moon, H.R., Choi, E.J., Kim, Y.O., Nam, B.H., Lee, S.J., and Ha, N.C. (2011). Crystallization and preliminary X-ray crystallographic analysis of Salmonella Typhimurium CueP. Acta Crystallogr. Sect. F Struct. Biol. Cryst. Commun. 67, 675-677. 